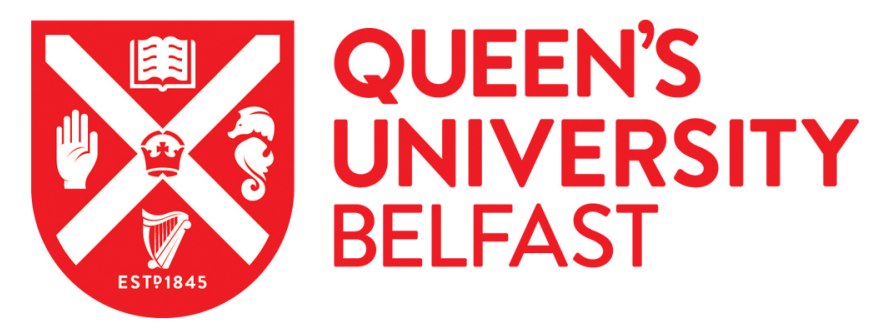

\title{
A case of repetitive penile fracture: an increasingly observed phenomenon.
}

McAuley, S. H. J., \& Walsh, I. (2016). A case of repetitive penile fracture: an increasingly observed phenomenon. Journal of Clinical Urology. https://doi.org/10.1177/2051415816664276

Published in:

Journal of Clinical Urology

Document Version:

Peer reviewed version

Queen's University Belfast - Research Portal:

Link to publication record in Queen's University Belfast Research Portal

Publisher rights

Copyright 2016 The Authors

\section{General rights}

Copyright for the publications made accessible via the Queen's University Belfast Research Portal is retained by the author(s) and / or other copyright owners and it is a condition of accessing these publications that users recognise and abide by the legal requirements associated with these rights.

Take down policy

The Research Portal is Queen's institutional repository that provides access to Queen's research output. Every effort has been made to ensure that content in the Research Portal does not infringe any person's rights, or applicable UK laws. If you discover content in the Research Portal that you believe breaches copyright or violates any law, please contact openaccess@qub.ac.uk. 


\section{Repetitive Penile Fracture: A Case Report}

A 41 year old male presented to the Emergency Department with a penile fracture after experiencing a sudden 'pop' sensation, acute onset of pain, and rapid detumescence, following an extreme bend of his erect penis during coitus one hour before. On examination, he had a grossly engorged penis, with a large haematoma at its base, deviating the penis to the right, with tenderness at the left base. He had not yet passed any urine since the incident, but nor had he any bloody discharge from his urethra. He was circumcised and the skin of the penile shaft and base remained intact. His scrotum and testes were normal. This was the patient's second penile fracture.

His previous fracture was nine years prior, also during sexual intercourse, for which he had urgent surgical correction. In this instance, his partner was in the superior position when his penis was thrust back with extreme downward angulation and a 'pop' sensation. His previous penile fracture occurred whilst he was standing, and forcibly thrusting his erect penis into the perineum and experiencing subsequent fracture. On both occasions he had alcohol in his system.

He underwent emergency exploration by a distal circumferential de-gloving of the penis from the corona down to the base, which allowed evacuation of the haematoma and revealed a $1 \mathrm{~cm}$ lateral tear in the left proximal corpus cavernosum, which was sutured with 3.0 Vicryl to create a watertight seal. Following an uneventful recovery, he was discharged home the following day along with a seven-day course of per oral antibiotics (Co-amoxiclav 625mg TDS).

A penile fracture is a rare occurrence and a urological emergency. To experience a second penile fracture is an added particular rarity. Was there a predisposition for penile fracture due to an underlying histological abnormality, had the previous fracture rendered the penis prone to further fracture by weakening at or around the fibrotic scar of the repair, or was this simply a matter of unsafe practice?

\section{Discussion}

A Penile fracture describes the tunica albuginea, an expansible fascia of high tensile strength, and the corpora cavernosa, two chambers of erectile elastic tissue that fill with blood during an erection and which is enveloped by the tunica albuginea, rupturing as a result of blunt trauma to the erect penis.

When erect, the tunica albuginea thins from an average $2 \mathrm{~mm}$ to $0.25 \mathrm{~mm}$, and maintains a mean intra-cavernosal arterial pressure of $100 \mathrm{mmHg}$, and has an ability to withstand pressures of up to $1500 \mathrm{mmHg}$ 1,2,3. Penile Fracture often results from extreme angulation of the erect penis, creating an overwhelming intra-cavernosal pressure and then a sudden rupture of the taut coronal bodies, often with the pathognomonic 'pop.'

Our literature review identified only nine cases of repetitive penile fractures. Seven of these repetitive fractures occurred on the ipsilateral corpus cavernosum, with just two cases occurring on the contralateral corpus $4,5,6,7,8,9,10,11,12$. An ipsilateral re-occurrence would suggest a fibrous scar liable to fracture on further insult, or possibly that the fibrous scar created a weaker contiguous tunica fascia prone to buckling when erect, and at pressures inferior to the usual stresses required to rupture normal albuginea.

A review of the original operation note from January 2006, revealed his first penile fracture had actually occurred on the right corpus cavernosum, creating a $2 \mathrm{~cm}$ vertical split on its ventral aspect. His second fracture, in September 2015, resulted in a 
proximal lateral split of the left corpus cavernosum, contralateral and distal to the original fracture. This implies that the previous fracture had no bearing on the second injury, and there have been an underlying cellular structural abnormality predisposing to further fracture.

De Rose et al revealed histological evidence of a chronic inflammatory process in the tunica albuginea that may so predispose to penile fracture. In five out of six cases of penile fracture, in comparison with normal albuginea, histology revealed fibrosclerosis and lymphocytic cellular infiltrates appearing to weaken the corpora cavernosa and predispose the penis to fracture, and possibly under intra-cavernous pressures less than usual to necessitate a rupture in normal healthy albuginea ${ }^{3}$.

It has also been suggested that scar tissue from a previous penile fracture can create a source of unequal distribution of tension in the tunica albuginea that leads to rupture of the contralateral side ${ }^{12}$.EXPAND ON THIS A BIT (one sentence should do)

In western societies, certain sexual positions have been identified as a risk for penile fracture, including having the partner in the superior position, planting their entire body weight on the erect penis; and rear-entry coitus, when the erect penis is thrust into the perineum, particularly during vigorous intercourse; the two positions relevant to this case report. Anecdotally, young men are also considered most at risk, due in part to the athleticism of their actions but also the rigidity of their phallic erections.

In Iran, a practice of manual manipulation to achieve detumescence, Taghaandan, has been observed to be responsible for the majority of penile fractures in that region. Taghaandan, a cultural practice of forcibly hiding an erection; is a self-inflicted, downward bending of the distal aspect of the erect penis, with the lower shaft held stationary, until a click is heard or felt, that induces a rapid detumescence, but has also been culpable for more than two thirds of reported penile fractures in $\operatorname{Iran}^{13}$.

This patient had emergency surgical repair of the penile fracture within 12 hours of occurrence. Case studies on the long-term follow up of early surgical repair have exhibited superior preservation of erectile potency and speedier recovery times, in comparison with conservative management, the once standard of care for penile fracture, which often involved cold compresses, anti-inflammatories and anti-androgens to suppress any erection 2,14,15. Eight weeks following his surgical repair, this gentleman was able to achieve erections and ejaculate normally, however he had_difficulty prolonging his erection, due to anxiety of reoccurrence.

The patient also completed a course of antibiotics, despite the empirical value of such having yet to be substantiated. Routine broad-spectrum antibiotic cover in the pre- and perioperative period appear to be the subjective norm, and not the rule, with no clear consensus amongst authors as to its merits. Concerns regarding urethral injury, urinary retention, catheterization and possibility of clean-contaminated wounds may validate antibiotic administration.

\section{Conclusion}

We highlight a rare case of repetitive penile fracture to identify possible aetiologies and to whether a penile fracture predisposes to an increased liability to fracture in future. This is also the third reported case to identify a repetitive penile fracture that re-occurs distal to the site of the original fracture, and on the contralateral corpus cavernosa. This would negate the assumption that the original fracture had compromised the immediate 
tunica albuginea to increased fracture risk, but rather suggests a causal histological structural abnormality, and lends support to evidence of histological fibrosclerosis and lymphocytic cellular infiltrates that weaken albuginea and the corporal tissues, causing them to fracture under lesser pressures required to rupture normal albuginea.

Further to early surgical repair, we recommend tunica albuginea tissue sampling to identify any causal histological aetiology: Practical advice on the prevention of future fracture should include avoiding prone sexual positions, particularly under the influence of alcohol.

\section{References}

1. Asgari MA, Hossieni SY, Safarinejad MR, Samadzadeh B, Bardideh AR. Penile fracture: evaluation, therapeutic approaches and long term results. J Urol 1996; 155: 148-9

2. Kamdar, C., Mooppan, U.M.M., Kim, H. and Gulmi, F. A. (2008), Penile fracture: preoperative evaluation and surgical technique for optimal patient outcome. BJU International, 102: 1640-1644

3. De Rose AF, Giglio M, Carmignani G. Traumatic rupture of the corpora cavernosa: new physiopathologic acquisitions. Urology. 2001 Feb; 57(2):319-22.

4. Kattan $S$, Youssef A, Onuora V, Patil M. Recurrent ipsilateral fracture of the penis. Injury 1993; 24:685-6.

5. Punekar SV, Kinne JS. Penile refracture. BJU Int 1999; 84:183-4.

6. Koifman L, Cavalcanti AG, Manes CH, Filho DR, Favorito LA. Penile fracture Experience in 56 cases. Int Braz J Urol 2003; 29:35-9.

7. Pandyan GV, Zaharani AB, Al Rashid M. Fracture penis: An analysis of 26 cases. Scientific World Journal 2006; 6:2327-33.

8. Mir SA, Wani MD. Recurrent Penile Fracture. World Journal of Medical and Surgical Case Reports. 2013 Jul 27; 2(14).

9. Swanson DE, Polackwich AS, Helfand BT, Masson P, Hwong J, Dugi DD $3^{\text {rd }}$, et al. Penile fracture: Outcomes of early surgical intervention. Urology 2014; 84:1117-21

10. Ridyard DG, Phillips EA, Munarriz R. Recurrent Penile Fracture: A Case Report and Review of Literature. J Integr Nephrol Androl 2015; 2:132-4

11. Du J, Mason DF, Broome KE. Penile fracture: Second episode in 5 years. ANZ J Surg 2012; 82:856

12. S. Sharma, M. Suryavanashi, S. Sharma, S. Singh, A Sethi and NP Gupta. Contralateral fracture of penis with concomitant urethral injury - report of a rare case. African Journal of Urology 2009; Vol. 15, No. 2: 103-106.

13. Zargooshi J. Penile fracture in Kermanshah, Iran: report of 172 cases. J Urol 2000; 164: 364-366.

14. Gamal WM, Osman MM, Hammady A, Aldahshoury MZ, Hussein MM, Saleem M. Penile fracture: long-term results of surgical and conservative management. $J$ Trauma. 2011 Aug; 71(2): 491-3.

15. Jack GS, Garraway I, Reznichek R, Rajfer J. Current Treatment Options for Penile Fractures. Reviews in Urology. 2004; 6(3): 114-120. 